Tomasz Kubalica

Uniwersytet Śląski, Katowice

ORCID: 0000-0001-7585-7138

e-mail: tomasz.kubalica@us.edu.pl

\title{
Kontrowersje wokół autoryłetu w świetle analiz Józefa M. Bocheńskiego na tle współczesnej recepcji idei Oświecenia
}

Jedną z głównych idei Oświecenia jest wolność w myśleniu - słynne sapere aude. Zakłada ona wolnomyślicielskie przekonanie o wolności każdego człowieka w zakresie kształtowania własnego myślenia. Takie przekonanie znajduje się na kursie kolizyjnym z zastanymi poglądami, w szczególności stoi w opozycji do różnego rodzaju autorytetów. Zasadnicze pytanie polega na tym, czy konflikt jest nieunikniony. Czy wolność myślenia musi polegać na podważaniu zastanych autorytetów? Czy w konsekwencji wolność myślenia jest wolnością od autorytetu? Wbrew pozorom taka negatywnie rozumiana wolność ogranicza nas, gdyż skazuje na bezkrytyczną nieufność wobec olbrzymich zasobów wiedzy zebranych przez ludzkość i izoluje nas od społeczeństwa wiedzy. Jeśli zatem wolność nie polega na zanegowaniu autorytetów, to musi zakładać jakąs inną możliwość konfrontacji z autorytetem, która nie będzie destruktywna dla wiedzy godnej zaufania. To prowadzi nas do zasadniczego pytania, które stawiam za Józefem M. Bocheńskim w niniejszym artykule.

Problem autorytetu doczekał się współcześnie bardzo wielu omówień w literaturze. Do najważniejszych pozycji należy przede wszystkim tekst Hanny Arendt What is Authority? z 1961 roku1, w którym wybitna

${ }^{1}$ Hannah Arendt, "What Is Authority?", w: Between the Past and the Future. Six Exercises in Political Thought (New York: The Viking Press, 1961), 91-142; tejże, „Co to 
uczennica Martina Heideggera i Karla Jaspersa podejmuje tytułową kwestię współczesnego rozumienia autorytetu w czasach jego kryzysu. Choć punktem wyjścia jest polityczne rozumienie autorytetu, to jednak Arendt traktuje go bardzo szeroko i rozciąga również na wychowanie dzieci i edukację szkolną. Źródła kryzysu upatruje w dwóch błędach w sposobie rozumienia autorytetu. Pierwszy polega na utożsamieniu autorytetu z przemoca, a drugi $-\mathrm{z}$ antyegalitaryzmem. Kwestie rozumienia autorytetu jako przemocy Arendt ujmuje następująco: „Ponieważ autorytet zawsze wymaga posłuszeństwa, przeto nagminnie bywa mylony z różnymi formami siły i przemocy. A przecież tak naprawdę wyklucza on używanie zewnętrznych środków przymusu"2. Autorytet kieruje się maksymą uniwersytecką plus ratio quam vis i dlatego nie da się go utożsamić z jakąkolwiek formą przemocy, nie tylko fizycznej, co jest oczywiste, lecz również psychicznej, która jest trudniejsza do zauważenia i zdefiniowania.

Bardzo wyraźnie w kontekście Oświecenia zostaje postawiona kwestia autorytetu przez Paula Ricœura w tekście Le paradoxe de l'autorité ${ }^{3}$ z 1995 roku, w którym podejmuje on polemikę z Arendt. Ricœur podobnie jak Arendt utożsamia autorytet $\mathrm{z}$ jego politycznym oraz instytucjonalnym wymiarem i dochodzi do zbliżonego przekonania:

dzisiaj mamy poczucie, że tkwimy w samym centrum kryzysu uprawomocnienia i - powiedzmy to - braku wiarygodności autorytetu, władz publicznych, instytucji bądź osób; kryzysu podkreślanego ogólnym milczeniem $w$ kwestii udzielania komuś zaufania, to znaczy uznawania wyższości kogokolwiek, jednostki bądź instytucji, kto miałby być wyposażony w możność narzucania posłuszeństwa ${ }^{4}$.

Analizując tak postawiony problem, stawia w centrum swoich rozważań kwestię uprawomocnienia autorytetu i za Gerardem Leclerkiem przyjmuje, że należy odróżnić uprawomocnienie autorytetu odwołującego się do wypowiedzi (autorite enonciative) od uprawomocnienia autorytetu instytucjonalnego (autorite institutionelle). Autorytet dla niego zawsze jest rodzajem władzy, ale jest to władza symboliczna autora wypowiadającego jakąś treść, która polega na wzbudzaniu zaufania i stosowaniu określonego rodzaju perswazji. W przeciwieństwie do

jest autorytet?", w: Między czasem minionym a przyszłym. Osiem ćwiczeń z myśli politycznej, przeł. Mieczysław Godyń, Wojciech Madej (Warszawa: Aletheia, 2011), 109-73.

2 Arendt, "Co to jest autorytet?", 110.

3 Paul Ricœur, „Le paradoxe de l'autorité”, Philosophie, Bulletin de Liaison des professeurs de philosophie de l'académie de Versailles, C.R.D.P. 7 (1995): 6-12; tenże, „Paradoks autorytetu", w: Oświecenie dzisiaj. Rozmowy w Castel Gandolfo, przeł. Jacek Migasiński (Kraków: Znak, 1999), 29-44.

${ }^{4}$ Ricœur, „Paradoks autorytetu”, 32. 
niej władza instytucjonalna narzuca posłuszeństwo. W tym kontekście Ricœur uważa, że

w autorytecie, który już zaniknął, istniała przewaga autorytetu odwołującego się do oznajmiania. To natomiast, co ja chciałbym zasugerować, to teza, że nigdy nie było czystego autorytetu odwołującego się wyłącznie do wypowiedzi bez autorytetu instytucjonalnego i że nie ma dzisiaj autorytetu czysto instytucjonalnego bez pewnego zaplecza, pewnego wsparcia symbolicznej instancji wypowiedzi ${ }^{5}$.

Dla Ricœura oba rodzaje autorytetu przenikają się nawzajem i jeden korzysta ze wsparcia drugiego.

Doniosłe dla naszych rozważań jest to, że Ricœur odnosi swoje refleksje do różnych modeli autorytetu, to znaczy zarówno do modelu średniowiecznego chrześcijaństwa, jak i do modelu Aufklärung, którego źródła znajdujemy w Oświeceniu. Jego zdaniem idealny model chrześcijaństwa stał się skostniały, gdyż „zdławił własne źródłowe zasoby kreatywności, które byłyby zdolne do wydobycia się na światło dzienne ponad podważającym go przeciwstawnym modelem idealnym oświecenia" ${ }^{\prime \prime}$. Oba konkurujące modele autorytetu są podobne, jeśli chodzi o ich podwójne, symboliczno-instytucjonalne źródła, ale różni je jednak to, co uznają za źródło wypowiedzi: dla chrześcijaństwa była nim Biblia, a dla Oświecenia francuskiego Wielka encyklopedia francuska. W tym kontekście Ricœur stwierdza, że „Encyklopedyści podzielali złudzenia obrońców rzymskiej ortodoksji katolickiej, będącej u progu swego zmierzchu, a mianowicie, że autorytetem, z którym należało walczyć, był par excellence autorytet dyskursu i że właśnie na tej płaszczyźnie symboli należało zasadniczo go pokonać"7. Oświecenie powtórzyło błędy chrześcijaństwa i doprowadziło do instytucjonalnego skostnienia autorytetu.

Przedmiotem artykułu jest jednak logika autorytetu Józefa M. Bocheńskiego, którą - moim zdaniem - należy potraktować jako próbę odpowiedzi na postawione wyżej pytanie o znaczenie autorytetu, mimo że jego ujęcie charakteryzuje czysto spekulatywny (niehistoryczny) charakter i dlatego poza wspomnieniem kilku filozofów nie zawiera większych odniesień do bogatej literatury przedmiotu. Przeprowadzona przez Bocheńskiego analiza kategorialna autorytetu, a w szczególności rozróżnienie autorytetu epistemicznego i deontycznego, stanowi jedno z jego najważniejszych osiągnięć filozoficznych. W rozważaniach opieram się na dwóch opublikowanych przez niego tekstach, w których przedstawił

\footnotetext{
5 Tamże, 33.

6 Tamże, 35.

7 Tamże, 39.
} 
swoje poglądy: dodatku Analysis of Authority do The Logic of Religion z 1965 roku $^{8}$ oraz rozprawie Was ist Autorität? z 1974 roku9.

Bocheński w Logice religii diagnozuje kwestię kryzysu autorytetu nie tylko na gruncie religii. Istoty kwestii kryzysu autorytetu na płaszczyźnie religijnej upatruje $\mathrm{w}$ tym, że "podmiot, który do pewnego momentu całkowicie polegał na autorytecie, czuje wątpliwości i stara się uzyskać bardziej racjonalne uzasadnienie swoich poglądów" ${ }^{\prime 10}$. Kryzysowi ulega zatem relacja autorytetu, która zostaje albo całkowicie podważona, albo poważnie osłabiona. Sam kryzys może zatem przybrać dwie postacie. W pierwszej - umiarkowanej - postaci podmiot decyduje się zweryfikować twierdzenia autorytetu i pogłębia swoją wiedzę, tak że chociaż pozostaje mu wierny, to jednak zastąpi jeden autorytet - znany z bezpośredniego doświadczenia - innym zracjonalizowanym przez wnioskowanie redukcyjne. W drugiej - radykalnej - postaci podmiot odrzuca wiarę we wszelki autorytet i przechodzi do uzasadnienia przedmiotowo-językowego, co kwituje słowami:

Dana religia jest bowiem dla nich [dla podmiotów radykalnie odrzucających autorytet] nie tylko tym, czego nauczyli ich starsi, ale także pewnym spojrzeniem na świat i istnienie, które wyjaśnia ich doświadczenie, co stanowi uzasadnienie swojego PD [podstawowego dogmatu] poprzez redukcję przedmiotowo-językową ${ }^{11}$.

Bocheński w omawianym przez nas suplemencie rozszerza przedstawiony zakres analizy i nie ogranicza jej tylko do kwestii autorytetu religijnego. Nie powraca także już do kwestii autorytetu religijnego jako takiego, lecz rozpatruje szerzej rozumiany autorytet epistemiczny i deontyczny.

Podobnie czyni w rozprawie Was ist Autorität?, w której konsekwentnie obstaje przy niehistorycznym ujęciu zagadnienia. Sam deklaruje

8 Joseph M. Bochenski, "Analysis of Authority”, w: The Logic of Religion (New York University Press, 1965), 162-73; Józef Maria Bocheński, „Analiza autorytetu”, w: Logika religii, przeł. Sławomir Magala (Warszawa: Instytut Wydawniczy Pax, 1990), 122-29; zob. też Józef Maria Bocheński, „Logika religii”, w: Logika i filozofia. Wybór pism, przeł. Sławomir Magala, Biblioteka Współczesnych Filozofów (Warszawa: Wydawnictwo Naukowe PWN, 1993), 458-66.

9 Joseph M. Bochenski, Was ist Autorität? Einführung in die Logik der Autorität (Freiburg: Verlag Herder, 1974); Józef Maria Bocheński, Qu'est-ce que l'autorité? Introduction à la logique de l'autorité, przeł. Philibert Secrétan, Études d'éthique chrétienne (Fribourg: Éditions Universitaires, 1979); tenże, "Co to jest autorytet?", w: Logika i filozofia: wybór pism, przeł. Jan Parys, Biblioteka Współczesnych Filozofów (Warszawa: Wydawnictwo Naukowe PWN, 1993), 187-324.

10 Joseph M. Bochenski, The Logic of Religion (New York University Press, 1965), $145-46$.

11 Tamże, 147. 
również, że jego badania nad autorytetem nie należą ani do socjologii, ani do psychologii, lecz właśnie do filozofii ${ }^{12}$. Chodzi mu o przeprowadzenie badań podstawowych nad założeniami innych nauk. Tego rodzaju filozofię określa on jako filozofię analityczna, która ma za zadanie badanie różnych znaczeń słów w celu lepszego określenia ich znaczenia i należy do logiku stosowanej, a konkretnie do logiki autorytetu ${ }^{13}$.

Innym ważnym motywem odniesienia się do poglądów Bocheńskiego, jako przedstawiciela dynamicznie rozwijającego się neotomizmu ${ }^{14}$, jest jego antymodernistyczne i w konsekwencji również antyoświeceniowe stanowisko. Oświecenie jako „ruch kulturowy mający na celu zastąpienie autorytetu religijnego, względnie politycznego, przez tzw. rozum" ${ }^{15}$ stanowi dla niego źródło zabobonów również $\mathrm{w}$ zakresie autorytetu. Racjonalizm wraz $\mathrm{z}$ jego wiarą $\mathrm{w}$ nieograniczony postęp naukowy przeciwstawia autorytetowi religijno-politycznemu. Krytycznie stwierdza jednak, że chociaż przyczyny powstania Oświecenia nie są całkowicie znane, to "pewną rolę odegrało jednak niewątpliwie nadużywanie autorytetu, zwłaszcza ze strony przedstawicieli religii, którzy zaczęli wyrokować o sprawach należących do dziedziny nauki, choć przedmiotem religii są sprawy pozaświatowe (egzystencjalne, metafizyczne itd.)"16. Antymodernistyczna i antyoświeceniowa postawa Bocheńskiego inspiruje do postawienia pytania, czy znalazł on odpowiednie remedium na kryzys autorytetu, który przecież obejmuje nie tylko autorytet eklezjalny, lecz również - usytuowany w opozycji do niego autorytet oświeceniowy.

Celem naszych rozważań nie jest jednak sama analiza założeń i konsekwencji logiki autorytetu, lecz jej usytuowanie w kontekście współczesnej dyskusji nad filozoficznym problemem autorytetu. Podejmuję próbę odpowiedzi na następujące pytania: (1) Czy Bocheński podejmuje kwestię autorytetu w zarysowanym wyżej kontekście kryzysu autorytetu? (2) Co wyróżnia sposób ujęcia autorytetu przez Bocheńskiego? (3) Jak bardzo jego ujęcie wyjaśnia problemy związane z pojęciem autorytetu? (4) Jakie aporie generuje przedstawiona przez Bocheńskiego logika autorytetu?

W artykule podejmuję próbę odpowiedzi na wyżej przedstawione pytania na podstawie historycznej analizy źródeł. Jej celem jest badanie autentyczności poglądów Bocheńskiego na autorytet oraz odczytanie

12 Bochenski, Was ist Autorität?, 13.

${ }^{13}$ Por. tamże.

${ }^{14}$ Czesław Głombik, „Józef M. Bocheński wobec tomizmu”, Przegląd Religioznawczy 1, 179 (1996): 83-108.

15 Józef Maria Bocheński, Sto zabobonów: krótki filozoficzny słownik zabobonów (Kraków: Philed, 1994), 93.

16 Tamże, 94. 
ich znaczenia $\mathrm{w}$ świetle przyczyn i warunków ich powstania w procesie historycznym. Dlatego rekonstrukcja poglądów Bocheńskiego opiera się na tekstach, które zostały opublikowane bezpośrednio przez autora, a nie na ich tłumaczeniach. Przekłady będące rodzajem opracowania tekstu źródłowego są wykorzystane tylko pomocniczo jako źródło wiedzy o pewnych interpretacjach poglądów Bocheńskiego. Z tego powodu $\mathrm{w}$ tej analizie historycznej opieram się na zawartych $\mathrm{w}$ tekstach źródłowych pojęciach, zakodowanych w symbolach logicznych użytych przez Bocheńskiego. Uznałem, że należy zrezygnować z formalizmów i skoncentrować się na treści pojęć.

Odpowiedź na pierwsze dwa pytania wydaje się względnie łatwa. Chociaż Bocheński nie odnosi się wprost do określonego ujęcia problemu autorytetu, to jednak wyraża jego świadomość. Istotne jest również, że jego pojęciowe dystynkcje wychodzą ponad dominujący w socjologii funkcjonalizm, który krytykuje Arendt. W tym sensie można udzielić pozytywnej odpowiedzi na pierwsze pytanie: Bocheński podejmuje kwestię autorytetu w zarysowanym wyżej kontekście kryzysu autorytetu, próbując naświetlić nieporozumienia związane ze sposobem jego rozumienia.

W odpowiedzi na drugie pytanie można powiedzieć, że sposób ujęcia autorytetu przez Bocheńskiego wyróżnia właśnie jego analityczne w sensie analizy kategorialnej ujęcie, które wychodzi od - zdawałoby się - trywialnych przesłanek, ale dochodzi do niebanalnych wniosków. Bocheński w swej analizie przedstawia autorytet jako relację triadyczną zachodzącą między autorytetem, podmiotem i polem (dziedziną) autorytetu. Polem autorytetu jest klasa wyrażeń znaczących, w odniesieniu do której posiadacz autorytetu to autorytet dla podmiotu autorytetu ${ }^{17}$. Swoją analizę Bocheński określa również jako logikę autorytetu, która zajmuje się tylko jego niektórymi najprostszymi, choć nie trywialnymi, aspektami, bada tak zwaną semiotyczną sytuację pragmatyczną, w jakiej znajduje się autorytet.

Najważniejszym - wskazanym przez samego autora analizy - osiągnięciem jest rozróżnienie dwóch rodzajów autorytetu - epistemicznego i deontycznego - na gruncie czysto logicznej analizy (teza 4.2), której znaczenie Bocheński wyjaśnia w następujący sposób:

Autorytet epistemiczny należy mianowicie do człowieka, który wie lepiej lub więcej niż podmiot. Tak na przykład autorytet nauczyciela wobec studenta jest epistemiczny. To jest autorytet kogoś znającego się na rzeczy.

17 Bochenski, „Analysis of Authority”, 163; tenże, Was ist Autorität?, 23; Por. Filip Kobiela, „Autorytet epistemiczny w sytuacji epistemicznej”, Filozofia Nauki XXIV, 1, 93 (2016): 124. Kobiela zwraca uwagę na to, że rozbieżna terminologia zastosowana w tłumaczeniach obu tekstów może prowadzić do nieporozumień. 
Co się tyczy autorytetu deontycznego, to nie należy on do tego, kto wie lepiej, lecz do przełożonego, szefa, dowódcy, kierownika itd. ${ }^{18}$

Oba autorytety nie wykluczają się wzajemnie, a nawet mogą współwystępować między tymi samymi ludźmi. Kategorialnie odnoszą się jednak do dwóch różnych, ale ściśle związanych, dziedzin: autorytet epistemiczny - do klasy zdań orzekających (propositions), a autorytet deontyczny - do klasy dyrektyw.

Choć Bocheński nie deklaruje wprost, że podnosi kwestię kryzysu autorytetu, wydaje się, że jego propozycję można odnieść do dyskutowanego kryzysu autorytetów. Moim zdaniem Bocheński, dokonując uściślenia sposobu rozumienia autorytetu i związanych z tym dystynktywnych rozróżnień, wnosi cenny wkład do dyskusji nad problemem, co spróbuję w dalszym wywodzie uzasadnić.

Przedmiotem rozważań Arendt oraz Ricœura był przede wszystkim autorytet polityczny. Główny problem związany z kryzysem autorytetu filozofka opisuje w następujący sposób:

Ponieważ autorytet zawsze wymaga posłuszeństwa, przeto nagminnie bywa mylony z różnymi formami siły i przemocy. A przecież tak naprawdę wyklucza on używanie zewnętrznych środków przymusu ${ }^{19}$.

Mówiąc językiem Bocheńskiego, koniecznym warunkiem zajścia relacji autorytetu jest posłuszeństwo podmiotu wobec autorytetu, ale podstawą tej relacji nie może być przemoc i siła, a w szczególności źródłem autorytetu nie mogą być zewnętrzne środki przymusu. Bocheński się z tym zgadza i rozumie autorytet $\mathrm{w}$ jego poszczególnych dystynkcjach jako pewnego rodzaju władzę posiadacza autorytetu nad jego podmiotem, co uzasadnia przeprowadzane przez nas porównanie, gdyż istnieje wspólna płaszczyzna porównania.

W tym kontekście należałoby wyjaśnić, co rozumiemy przez przemoc. Wydaje się, że najbardziej oczywistym jej przejawem jest agresja fizyczna, którą charakteryzuje ingerencja w ciało ofiary przemocy i swobodna aktywność. Stopień ingerencji naruszającej strukturę fizyczną ciała może przybierać różne formy, nie ograniczając się wyłącznie do pozbawienia życia, i obejmować spowodowanie ran oraz innych obrażeń - które mogą być trwałe lub nie - czy też naruszenie prawa do nietykalności cielesnej. Fizyczny charakter ma również przemoc w postaci uprowadzenia, uwięzienia, naruszenia miru domowego itp.

Mniej wyraźna i bardziej zróżnicowana jest przemoc psychiczna, która niejednokrotnie łączy się z elementami przemocy fizycznej. Do tej

18 Bochenski, Was ist Autorität?, 53.

19 Arendt, „Co to jest autorytet?", 110. 
grupy należą takie formy przemocy, jak: groźby, uporczywe nękanie (stalking), wymuszenia, ale również ataki werbalne w postaci zniewagi lub publicznego zniesławienia. Specjalną kategorią przemocy jest przemoc seksualna, do której należą: gwałt, wykorzystanie osoby upośledzonej lub nieletniej, kazirodztwo, prezentowanie pornografii małoletnim, a nawet utrwalanie czynności seksualnej bez zgody osoby, która jej podlega. Istnieje również przemoc ekonomiczna w relacjach małżeńskich. Przemoc nie musi mieć charakteru aktywnego, lecz może być zupełnie pasywna, tak jak w przypadku porzucenia lub zaniedbania dziecka. $Z$ pewnością nie jest to wyczerpujące wyliczenie wszystkich rodzajów przemocy, niemniej jednak to pozwala na ukształtowanie wyobrażenia wystarczającego do udzielenia odpowiedzi na pytanie, czy przemoc jest wpisana w relację autorytetu.

W odpowiedzi na to pytanie można stwierdzić, że nie da się pogodzić koncepcji autorytetu epistemicznego z żadną formą przemocy, nie tylko fizycznej, ale również psychicznej. Przemoc fizyczna w sposób oczywisty wyklucza relację autorytetu. Trudno również wyobrazić sobie przypadek, że ofiara napaści psychicznej będzie podmiotowo, czyli zupełnie swobodnie, uznawać napastnika za autorytet. Swoboda w uznaniu kogoś za autorytet jest przyjęta przez Bocheńskiego raczej domyślnie, jednak trudno to inaczej zinterpretować bez popadania $w$ nadinterpretację.

Należy zauważyć, że w przeciwieństwie do Arendt, która uważa, iż porządek hierarchiczny autorytetu „kłóci się z egalitarnym porządkiem perswazji" ${ }^{20}$, Bocheński hierarchiczność dostrzega tylko w autorytecie deontycznym, który - w przeciwieństwie do autorytetu epistemicznego - może być delegowany na inne osoby. Inaczej niż hierarchiczny autorytet deontyczny ",autorytet epistemiczny należy [...] do człowieka, który wie lepiej lub więcej niż podmiot" ${ }^{21}$. Dla niego stanowi on autorytet znawcy rzeczy, na przykład nauczyciela, który wprawdzie zakłada różnice $\mathrm{w}$ stanie wiedzy, ale nie wyklucza możliwości, że uczeń przerośnie nauczyciela i samodzielnie stanie się autorytetem. W przypadku hierarchicznego autorytetu deontycznego jego podmiot - a tym bardziej delegat - nie może samodzielnie mianować się autorytetem.

Zdaniem Arend jednym ze źródeł kryzysu jest egalitaryzm, który podważa wszelkie hierarchie, w tym również autorytetu. Arendt podkreśla w tym kontekście, że „nie można go [autorytetu] kojarzyć z perswazja która zakłada równość i działa za pośrednictwem procesu argumentacji. Tam, gdzie używa się argumentów, tam autorytet pozostaje w stanie zawieszenia, ponieważ jego porządek - zawsze hierarchiczny - kłóci się z egalitarnym porządkiem perswazji" ${ }^{22}$. Chodzi o to, że

20 Tamże, 111.

${ }^{21}$ Bochenski, Was ist Autorität?, 53.

${ }^{22}$ Arendt, „Co to jest autorytet?", 111. 
relacja dialogiczna, która towarzyszy dyskusji i wymianie argumentów, powoduje zawieszenie hierarchii autorytetu nie tylko politycznego, co w warunkach demokracji wydaje się oczywiste, ale przede wszystkim nauczycielskiego, co jest bardziej istotne i rodzi więcej pytań. Jeżeli w dyskusji z uczniem relacja autorytetu nauczyciela wobec ucznia zostanie przynajmniej tymczasowo zawieszona, to odzyskanie autorytetu przez nauczyciela po zakończeniu debaty nie jest prostą sprawa, szczególnie wtedy, gdy nauczyciel będzie zmuszony siłą racji uznać argumenty ucznia.

Moim zdaniem zorientowana na polityczne aspekty kryzysu autorytetu Arendt nie dostrzega, że są jeszcze inne rodzaje autorytetu, takie jak autorytet epistemiczny. Jego specyfika polega na tym, że w tym przypadku argumentacja (merytoryczna) wcale nie zawiesza autorytetu wiedzy, gdyż może ona trafić tylko do podmiotu otwartego na wiedzę. Osoba, która nie jest otwarta na racjonalną perswazję ze strony autorytetu epistemicznego, w ogóle nie znajduje się w relacji autorytetu.

W tym miejscu napotykamy pewną aporię, która - moim zdaniem ma źródło w analitycznej metodzie Bocheńskiego. Niewątpliwą zaletą tej metody jest klarowność ujęcia problemu, wadą zaś - jej statyczność. Obraz otrzymany w wyniku analizy kategorialnej prezentuje pewne artefakty polegające na tym, że zaprezentowana relacja autorytetu wygląda tak, jakby była stała i niezmienna. Niestety ujęcie złożonej dynamiki relacji autorytetu wymyka się przyjętej metodzie. W logice autorytetu jest bardzo wyraźnie nakreślona relacja autorytetu między jego posiadaczem a podmiotem, ale nie jest wystarczająco wyraźnie powiedziane, że to właśnie podmiot autorytetu uznaje autorytet tej osoby, która go posiada. A przecież dynamika tej relacji przebiega w ten sposób, że posiadacz autorytetu jako określonej cechy (kompetencji) poprzedza nawiązanie właściwej relacji autorytetu, ale w nawiązywaniu tej relacji istotną rolę odgrywa podmiot, od którego wychodzi akt uznania autorytetu jego posiadacza.

Bocheński do pewnego stopnia zdaje sobie sprawę z ograniczeń analizy kategorialnej, gdy rozważa w rozdziale trzecim kwestię, czy można być autorytetem dla samego siebie. Jako przykład podaje sytuację, gdy autor, czytając własne notatki z przeszłości, pozostaje autorytetem dla siebie w kwestii tego, co wtedy robił. Bocheński ostatecznie uznaje, że „ja wówczas nie jest dokładnie tym samym indywiduum co teraz"23. Stąd wyciąga wniosek, że relacja autorytetu jest relacją niezwrotną (3.1). Uzasadnienie Bocheńskiego ukazuje jednak zasadnicze ograniczenie zastosowanej metody, która zakłada analizę w odniesieniu do tego samego momentu na linii czasu. Skądinąd wiemy jednak, że relacje autorytetu nie zachodzą tylko w jednym momencie, lecz kształtują się - powstaja

\footnotetext{
${ }^{23}$ Bochenski, Was ist Autorität?, 38.
} 
rozwijają się i zanikają - w pewnym okresie. Ponadto Bocheński rozważa tylko kwestie zwrotności w szczególnej relacji autorytetu wobec samego siebie. Zacytowany argument nie ma zastosowania do sytuacji, kiedy autorytetem i jego podmiotem są różne osoby.

Można przypuszczać, że statyczne ujęcie relacji autorytetu przyczyniło się do opacznego polskiego tłumaczenia, w którym podmiot autorytetu został nazwany przedmiotem ${ }^{24}$. Analiza historyczno-źródłowa pokazuje, że Bocheński konsekwentnie stosuje w języku angielskim i niemieckim termin "podmiot” na oznaczenie osoby uznającej. Układ pojęć $\mathrm{w}$ analizowanych pismach i tłumaczeniach wygląda następująco:

\begin{tabular}{|l|c|c|c|}
\hline & \multicolumn{3}{|c|}{$\begin{array}{r}\text { Składniki relacji autorytetu podane } \\
\text { we fragmencie 51.1 The Logic of Religion } \\
\text { oraz w twierdzeniu 1.2 Was ist Autorität? }\end{array}$} \\
\hline \multicolumn{1}{|c|}{ Źródło pisane } & $\mathbf{1 .}$ & $\mathbf{2 .}$ & 3. \\
\hline The Logic of Religion (1965) & authority & subject & field \\
\hline Was ist Autorität? (1974) & Träger & Subjekt & Gebiet \\
\hline $\begin{array}{l}\text { Qu'est-ce que l'autorité? } \\
\text { (1979) - Philibert Secrétan }\end{array}$ & porteur & Sujet & domaine \\
\hline $\begin{array}{l}\text { Logika religii (1990) - } \\
\text { przeł. Sławomir Magala }\end{array}$ & autorytet & Podmiot & pole \\
\hline $\begin{array}{l}\text { Co to jest autorytet? (1993) - } \\
\text { przeł. Jan Parys }\end{array}$ & podmiot & Przedmiot & dziedzina \\
\hline
\end{tabular}

Konsekwentnie stosowana terminologia Bocheńskiego bardzo wyraźnie określa, że to właśnie osoba, która uznaje wiedzę eksperta, jest podmiotem tego autorytetu, a uznany ekspert, choć oczywiście też nie jest przedmiotem, to jest osoba, a tym samym pośrednio również podmiotem posiadającym autorytet. Sprawa się nieco komplikuje w relacji autorytetu deontycznego, gdyż trudno bez zastanowienia powiedzieć o podporządkowanym członku załogi okrętu, że to on jest podmiotem, a nie kapitan, choć $\mathrm{w}$ gruncie rzeczy tak właśnie sprawa wygląda. Jednak z pewnością inaczej jest $\mathrm{w}$ sytuacji autorytetu deontycznego sankcji, gdzie wyraźnie strona sankcjonująca ma aktywny charakter, a adresat sankcji jest bierny, czyli przedmiotowy. Podsumowując, należy stwierdzić, że statyczne ujęcie - mimo zalet metody analizy kategorialnej - zaciera podstawową prawdę, iż relacja autorytetu powstaje nie między podmiotem i przedmiotem, lecz między dwoma podmiotami, a jeśli już

${ }^{24}$ Bocheński, „Co to jest autorytet?". 
mówić o przedmiocie autorytetu, to jest nim właściwie dziedzina autorytetu.

W tym kontekście należy umiejscowić stwierdzenie Filipa Kobieli, że "skoro podmiot autorytetu także nazywany jest autorytetem (explicite $\mathrm{w}$ Logice religii i implicite w Co to jest autorytet?), to Bocheński de facto wyróżnia także trzecie rozumienie autorytetu - autorytet-osobę"25. Na podstawie analizy źródłowej tekstów Bocheńskiego można oczywiście również wyodrębnić taki - substancjalny - sposób rozumienia autorytetu, gdyż osoba ciesząca się autorytetem (a person who has authority), nazwana przez Bocheńskiego „autorytetem”, musi być w pewnym sensie podmiotem i nie może być przedmiotem ${ }^{26}$. Mój wniosek jest jednak taki, że trzecie - substancjalne - rozumienie autorytetu wprawdzie można odnieść do posiadacza autorytetu, ale podmiotowość w relacji autorytetu związana jest przede wszystkim z osobą uznającą autorytet. Takie rozumienie odpowiada również wyciągniętym przez Bocheńskiego logicznym konsekwencjom $\mathrm{z}$ uściślonych pojęć autorytetu $\mathrm{w}$ zakresie tak filozoficznie doniosłych kwestii, jak: racjonalizm, wolność, tolerancja, anarchizm i totalitaryzm.

Przechodząc do problemu przymusu, należy stwierdzić, że zasadniczo odmiennie przedstawia się kwestia relacji autorytetu deontycznego do przymusu. Ten rodzaj autorytetu przysługuje osobie przełożonego, czyli szefowi, dowódcy lub kierownikowi, a jego dziedziną jest klasa dyrektyw, czyli reguł postępowania. Choć oba rodzaje autorytetu mogą koncentrować się w tej samej osobie, to sytuacja najbardziej niepożądana jest taka, gdy „posiadacz autorytetu deontycznego bezprawnie uznaje się za autorytet epistemiczny", wtedy bowiem mamy do czynienia $\mathrm{z}$ nadużyciem autorytetu ${ }^{27}$.

Koniecznym warunkiem istnienia autorytetu deontycznego jest istnienie pewnego praktycznego celu, który leży w przyszłości i nie został jeszcze urzeczywistniony. Urzeczywistnienia tego celu pragnie autorytet, a podmiot autorytetu jest przekonany, że wypełnienie tego pragnienia jest niezbędne do realizacji tego celu; to oznacza, że uznanie przez podmiot celu wyznaczonego przez autorytet stanowi podstawę relacji autorytetu. $Z$ tego powodu istotna dla naszych rozważań jest teza 9.1:

Każdy autorytet deontyczny jest albo autorytetem sankcji, albo (również) autorytetem solidarności ${ }^{28}$.

${ }^{25}$ Kobiela, „Autorytet epistemiczny w sytuacji epistemicznej”, 125.

${ }^{26} \mathrm{~W}$ tym miejscu można pominąć podjętą przez Bocheńskiego kwestę autorytetu społeczności, gdyż w zasadzie mówi on wprost, że autorytetem jest jednostka ludzka tudzież świadoma osoba zdolna do przekazywania treści własnej świadomości innym, a zatem w sposób dorozumiany można uznać, że autorytet jest podmiotem.

27 Bochenski, Was ist Autorität?, 55.

${ }_{28}$ Tamże, 101; por. Bocheński, ",Co to jest autorytet?", 289. 
Autorytet solidarności odwołuje się do wspólnoty celów zachodzącej między autorytetem deontycznym a jego podmiotem. Jego egzemplifikacją są relacje między kapitanem tonącego statku a jego załogą i pasażerami, którzy w obliczu zagrożenia podporządkowują swoje działania jego poleceniom, żeby wyjść $\mathrm{z}$ opresji. $\mathrm{W}$ tej sytuacji przymus jest zewnętrzny wobec solidarnej wspólnoty kapitana, załogi i pasażerów.

Inaczej będzie $\mathrm{w}$ przypadku autorytetu sankcji, który Bocheński omawia na przykładzie relacji pan-niewolnik. Problem polega na tym, że historycznie rzecz traktując, niewolnictwo było instytucją do pewnego stopnia prawnie legitymowaną, co utrudnia odróżnienie prawnie dopuszczalnego autorytetu sankcji od prawnie niedopuszczalnego. Dla oddania istoty bezprawnej relacji autorytetu sankcji lepiej posłużyć się przykładem - również podanym przez Bocheńskiego - relacji gangsterskich $^{29}$. Chodzi o relację zachodzącą między gangsterem, który jest traktowany jako rodzaj pseudoautorytetu, a jego ofiarami, czyli podmiotami tego pseudoautorytetu. Gangsterem jest osoba, która w sposób bezwzględny i brutalny dąży do osiągnięcia zamierzonego celu. Cel gangstera nie jest celem podmiotu autorytetu. Struktura autorytetu sankcji jest bowiem taka, że celem transcendentnym podmiotu jest przede wszystkim uniknięcie sankcji karnej, która grozi w przypadku niepodporządkowania się celowi gangstera.

W przypadku autorytetu sankcji Bocheński odróżnia dwa rodzaje celów: immanentny i transcendentny ${ }^{30}$. Pierwszy jest instrumentalny w stosunku do drugiego, który jest finalny. W omawianym przykładzie wymuszenia między gangsterem i ofiarą zachodzi zgodność w zakresie celów immanentnych, to znaczy samego przekazania pieniędzy, ale zachodzi różnica $w$ celach transcendentnych, to znaczy ofiara oddaje pieniądze, bo chce uniknąć sankcji, a gangster chce odnieść korzyść. Autorytet gangstera jest uznany przez ofiarę głównie dlatego, że pragnie on, podporządkowując się jego woli, uniknąć grożącej mu sankcji. Ten rodzaj autorytetu zakłada, że związek między celem immanentnym a celem transcendentnym podmiotu powstaje na skutek aktu woli posiadacza autorytetu, to znaczy podmiot autorytetu musi zaakceptować narzuconą mu przy użyciu groźby teleologię relacji opartą na przemocy. Wprost przeciwnie będzie w przypadku solidarności, gdzie cele transcendentne autorytetu i podmiotu są identyczne, a związek między działaniem podmiotu i jego celem transcendentnym jest niezależny od woli samego posiadacza autorytetu (teza 9.3).

Bocheński w swoim ujęciu autorytetu sankcji oddaje istotę imperatywu kategorycznego Immanuela Kanta w jego podstawowym sformułowaniu: „postępuj tak, byś człowieczeństwa [ludzkości] tak w twej

29 Por. Bochenski, Was ist Autorität?, 101.

30 Zob. tamże, 101-102. 
osobie, jak i w osobie każdego innego używał zarazem jako celu, nigdy tylko jako środka"31. Bocheński tak jak Kant traktuje człowieczeństwo a w szczególności godność osoby - jako cel sam w sobie. W odniesieniu do omawianego przykładu pseudoautorytetu gangstera - ale również do przykładu właściciela niewolnika - podmiot autorytetu jest potraktowany przez posiadacza tak rozumianego autorytetu sankcji nie jako podmiot, lecz jako przedmiot i środek do jego własnego celu. Wprawdzie zachodzi zgodność immanentnej celowości między gangsterem i ofiara, jako że ofiara poddaje się woli napastnika, ale nadrzędny cel transcendentny jest celem tylko i wyłącznie gangstera, gdyż ostatecznie ofiara nie chce oddawać swoich pieniędzy gangsterowi. Można powiedzieć, że w odniesieniu do transcendentnej - heteronomicznej - celowości omawianej relacji nielegalnego autorytetu sankcji podmiot autorytetu staje się tylko środkiem. Wyjątek stanowi sytuacja legalnego autorytetu sankcji na przykład działających zgodnie z prawem sił policyjnych, gdyż wtedy należy odnieść się do wspólnoty państwa celów. Dalsza analiza logiki autorytetu na tle filozofii praktycznej Kanta wykracza poza przedmiot niniejszego opracowania.

Oba rodzaje autorytetu deontycznego pozbawiają podmiot wolności $\mathrm{w}$ tym zakresie, że przez uznanie autorytetu nie może on sam podejmować decyzji w danej dziedzinie, gdyż ceduje to prawo na posiadacza autorytetu. Struktura autorytetu deontycznego polega właśnie na tym, że jego podmiot ze względu na cel, do którego dąży, „rezygnuje z pewnej części swojej wolności" ${ }^{32}$. W przypadku autorytetu deontycznego solidarności czyni to dobrowolnie, a w autorytecie sankcji - pod przymusem. Istnieje zatem różnica dotycząca sposobu jego przeżywania: „Człowiek pod wpływem autorytetu solidarności czuje się wolny, natomiast [...] autorytet sankcji wywołuje przymus, który pozbawia podmiot jego wolności" ${ }^{33}$. Przemoc autorytetu, o którym pisze Arendt, można zatem utożsamić z przymusem działania pod wpływem autorytetu deontycznego sankcji. Niepożądana przemoc autorytetu polega na tym, że cele ostateczne (transcendentne) posiadacza autorytetu i podmiotu są rozbieżne, co skutkuje tym, iż podmiot autorytetu w związku z podporządkowaniem autorytetowi traci poczucie kontroli nad sytuacją.

W tym kontekście istotne staje się to, co Bocheński rozumie przez wolność. Przyjmuje on pozytywny sposób rozumienia wolności:

${ }^{31}$ Immanuel Kant, „Ugruntowanie metafizyki moralności”, w: Dzieła zebrane. Prolegomena do wszelkiej przyszłej metafizyki, która ma wystapić jako nauka. Ugruntowanie metafizyki moralności. Metafizyczne podstawy przyrodoznawstwa. Krytyka praktycznego rozumu, t. 3, red. Tomasz Kupś, przeł. Mirosław Żelazny (Toruń: Wydawnictwo Naukowe UMK, 2012), IV, 429.

32 Bochenski, Was ist Autorität?, 106.

33 Tamże, 105. 
Na czym polega owa wolność? Najprościej mówiąc, na tym, że człowiek, którego nazywamy „wolnym”, może coś uczynić w dziedzinie swojej wolności, że ma możliwość przeprowadzenia tej czynności ${ }^{34}$.

Wymienia on trzy rodzaje wolności - fizyczną, psychologiczną oraz polityczną - i omawia skomplikowane relacje między nimi. Ze względu na interesujące nas kwestie przemocy i przymusu istotne jest twierdzenie 10.3:

Podmiot jest w danej dziedzinie politycznie wolny wtedy i tylko wtedy, gdy nie ma dla niego autorytetu deontycznego $w$ tej dziedzinie ${ }^{35}$.

Brak autorytetu deontycznego w tej samej dziedzinie nie oznacza jednak, że wolność w ogóle nie jest warunkowana przez żaden autorytet deontyczny. Wręcz przeciwnie, istnienie autorytetu deontycznego w jednej dziedzinie może stanowić warunek możliwości wolności w innej dziedzinie. Na przykład autorytet policji wymuszający zasady ruchu drogowego znosi z jednej strony swobodę w tym zakresie, ale z drugiej strony warunkuje wolność bezpiecznego przemieszczania się do wybranego celu, którego organ bezpieczeństwa ruchu nie może wymusić. Zakres prawdziwości twierdzenia 10.3 jest wyraźnie zawężony do jednej i tej samej dziedziny, w której podmiot nie podlega autorytetowi deontycznemu. Jeśli zakres wolności politycznej jest wyznaczany przez autorytet deontyczny, to należy również przyjąć konsekwencję, że mamy dwa rodzaje wolności politycznej; pierwsza polega na wolności od autorytetu sankcji, a druga uwalnia od autorytetu solidarności ${ }^{36}$.

O ile oczywiste wydaje się, że wolność polityczna i wolność fizyczna są wzajemnie niezależne (twierdzenie 10.4), to zależność od wolności politycznej i psychologicznej jest mniej intuicyjna. Jak już zostało powiedziane, podleganie autorytetowi deontycznemu zakłada możliwość wyboru między różnymi działaniami, czyli zakłada wolność psychologiczną (twierdzenie 10.5). Jednakże paradoksalnie brzmi konsekwencja twierdzenia 10.3, że jeżeli wolność polityczna w określonej dziedzinie oznacza brak autorytetu deontycznego w tej dziedzinie, to brak wolności politycznej również zakłada wolność psychologiczną (10.6). Brzmi to absurdalnie, ale teza 10.6 jest po prostu odpowiednikiem tezy 10.4 i oznacza, że wolność polityczna i wolność psychologiczna, tak jak wolność fizyczna, są niezależne. Dalszy wywód Bocheńskiego na temat związku wolności politycznej z psychologiczną prowadzi do wniosku,

34 Tamże, 107 (podkreślenia - J.M. Bocheński); por. także Bocheński, „Co to jest autorytet?", 295.

${ }_{35}$ Bochenski, Was ist Autorität?, 109; por. tenże, „Co to jest autorytet?”, 296.

36 Tenże, Was ist Autorität?, 111. 
że wcale nie trzeba być wolnym psychologicznie, żeby być wolnym politycznie, co potwierdza przykładem, że człowiek umysłowo chory, czyli pozbawiony wolności psychologicznej, może być wolny politycznie.

Rozważania na temat wolności mają doniosłe konsekwencje dla sposobu rozumienia tolerancji, którą Bocheński pojmuje w następujący sposób:

Coś lub kogoś tolerować, być wobec [tego lub] niego tolerancyjnym znaczy znosić, ścierpieć to lub jego. Przyglądając się bliżej, jest to sytuacja, kiedy uważa się coś [lub kogoś] za nieprzyjemne, niedobre, niecelowe, ale mimo to powstrzymuje się przed zabronieniem tego. $\mathrm{Z}$ tego wynika również, że można byłoby tego zabronić, bo posiada się w tym przypadku autorytet ${ }^{37}$.

Chociaż można mówić o tolerancji wobec pewnych poglądów, które wyrażają się w zdaniach, co sugerowałoby możliwość tolerancji epistemicznej, to jednak Bocheński zdecydowanie wyklucza taki rodzaj tolerancji i dopuszcza tylko tolerancję deontyczna, czyli w dziedzinie dyrektyw (twierdzenie 10.9). Zarówno ktoś powstrzymujący się przed zakazywaniem określonych poglądów, jak i wyraźnie nieodrzucający mniemań, które uważa za fałszywe, jest tolerancyjny deontycznie, gdyż nie chodzi tutaj o same mniemania, lecz o ich wyraźnie „zewnętrzny ludzki czyn". Bocheński uzasadnia to następująco:

Posiadanie poglądów jest już czynem, a człowieka nietolerancyjnego wprawia w złość, że nie ma takiej władzy, aby swojej ofierze narzucić mocą autorytetu odpowiedni nakaz ${ }^{38}$.

Takie ujęcie sprawy ma dwie konsekwencje. Po pierwsze, należy przyjąć, że posiadacz autorytetu powinien wykazywać tolerancję wobec tego, że nie jest autorytetem dla wszystkich. Nietolerancja może nie stanowi jeszcze objawu braku podstaw do bycia autorytetem, ale wskazuje na jego słabość w dziedzinie psychospołecznej. Można uznać, że jest widomym objawem kryzysu autorytetu.

Po drugie, sposób zawężenia tolerancji do tolerancji deontycznej, który polega na tym, że chodzi raczej o tolerancję wobec posiadanych poglądów niż o ich wartość poznawcza, sugeruje, że podstawowy podział na autorytet epistemiczny i deontyczny wcale nie jest ostry. Dzieje się tak, ponieważ również w odniesieniu do wszystkich zdań autorytetu epistemicznego można powiedzieć, że na płaszczyźnie pragmatycznej stanowią one wyraz posiadanych poglądów, a to oznacza, że taki autorytet epistemiczny jest również $\mathrm{w}$ pewnym sensie autorytetem

\footnotetext{
37 Tamże, 111.

38 Tamże, 112.
} 
deontycznym. To samo w sobie nie może być jeszcze zarzutem, gdyż Bocheński wyraźnie przyjął w twierdzeniu 4.3, że „Posiadacz autorytetu deontycznego $\mathrm{w}$ danej dziedzinie może równocześnie posiadać autorytet epistemiczny w odpowiadającej jej dziedzinie" ${ }^{\prime \prime 39}$, co oznacza, że nie są one rozłączne, czyli między autorytetem deontycznym i epistemicznym zachodzi relacja krzyżowania się zakresów. Niemniej jednak takie ujęcie rodzi pytanie, na które Bocheński nie dał odpowiedzi wprost: czy autorytet deontyczny autorytetu epistemicznego jest raczej autorytetem sankcji, czy też solidarności?

W związku z kwestią wolności deontycznej pojawia się problem anarchizmu, który polega na kwestionowaniu autorytetu deontycznego (twierdzenie 10.10), podobnie jak racjonalizm odrzuca autorytet epistemiczny. Różnica między nimi polega na tym, że „racjonalista uważa, że nie istnieje żaden autorytet, natomiast anarchista przyjmuje raczej, iż takowy (niestety) istnieje, twierdzi jednak, że nie powinien istnieć" ${ }^{40}$. Dalej Bocheński przedstawia trzy możliwe rodzaje anarchizmu: (1) anarchizm radykalny, odrzucający zarówno autorytet sankcji, jak i autorytet solidarności, (2) anarchizm sankcji i (3) anarchizm solidarności. Ten ostatni, trzeci, uznaje za praktycznie niemożliwy, bo ktoś odrzucający nawet autorytet solidarności, tym bardziej odrzuci autorytet sankcji (twierdzenie 10.11).

Ostatecznie jednak nie tylko anarchizm solidarności uznaje on za niemożliwy. Jego zdaniem anarchizm sankcji jest możliwy do przeprowadzenia pod względem „logicznym jak najbardziej, ale niestety nie ze względów psychospołecznych. Jak się wydaje, ludzie mają taką naturę, iż potrzebują autorytetu sankcji" ${ }^{41}$. Ponieważ anarchizm solidarności jest praktycznie niemożliwy, a anarchizm sankcji - choć jest możliwy, to okazuje się sprzeczny z ludzką natura, zatem tym bardziej należy przyjąć, że anarchizm radykalny, choć jest możliwy do wyobrażenia, to tylko w prostych sytuacjach granicznych. Natomiast w okolicznościach, które nie są oczywiste, nie można się obejść bez autorytetu. Dzieje się tak, gdyż anarchizm radykalny jest destrukcyjny i na dłuższą metę uniemożliwia osiągnięcie celu grupy z wyjątkiem bardzo prostych sytuacji (twierdzenie 10.12).

W przeciwieństwie do anarchizmu totalitaryzm jest dla Bocheńskiego „doktryna, według której powinien istnieć autorytet deontyczny we wszystkich dziedzinach" (twierdzenie 10.13) (2) $^{42}$ Totalitaryzm nie pozostawia żadnej dziedziny wolną od autorytetu deontycznego i może być

\footnotetext{
39 Tamże, 54.

40 Tamże, 112.

41 Tamże, 116.

42 Tamże, 117.
} 
albo totalitaryzmem radykalnym (sankcji), albo totalitaryzmem solidarności. W totalitarnym ideale społecznym

ludzie (wszyscy ludzie) we wszystkich dziedzinach podlegają autorytetowi sankcji [...], którego [posiadacz] może wszystkim ludziom nakazać, co powinni czynić, oraz może ich karać, jeśli tego nie uczynią [...]. Druga odmiana totalitaryzmu [autorytetu solidarności] wymaga tego samego, aczkolwiek tutaj podmioty autorytetu poddają się woli posiadacza dobrowolnie, ponieważ mają wspólny cel i postrzegają swoje posłuszeństwo za konieczne do osiągnięcia owego celu ${ }^{43}$.

Bocheński przestrzega przed tym, że o ile anarchizm jest ideałem, którego szansa urzeczywistnienia jest niewielka, to "totalitaryzm przeciwnie, nie napotyka trudności tego rodzaju"44. Najważniejsze jednak jest to, że między anarchizmem a totalitaryzmem nie ma sprzeczności, lecz występuje przeciwieństwo, które umożliwia drogę pośrednia, czyli ideał, który dopuszcza istnienie autorytetu deontycznego w pewnych dziedzinach, ale nie we wszystkich, pozostawiając obszar wolny od tego autorytetu, czyli obszar wolności politycznej.

Przechodząc do wniosków, przedmiotem artykułu była próba oceny logiki autorytetu w obliczu jego kryzysu. Uważam, że analizę Bocheńskiego można i należy potraktować jako formę intelektualnej odpowiedzi na strach przed totalitarnym autorytetem, który znajduje się u podstaw kryzysu autorytetu, gdyż zawęża on związek autorytetu z przymusem wyłącznie do autorytetu deontycznego sankcji. To oznacza, że w większości przypadków zachodzenia relacji autorytetu przemoc fizyczna i psychiczna jest wykluczona $z$ tej relacji. Odpowiedzią na skądinąd uzasadniony lęk przed totalitaryzmem jest klarowne określenie, kiedy autorytet deontyczny staje się totalitaryzmem. To oznacza, że dopóki istnieją enklawy wolności od autorytetu deontycznego, dopóty nie można mówić o zagrożeniu tyranią totalitaryzmu. W szczególności istotne jest to, że autorytet epistemiczny sam w sobie nie jest zagrożeniem dla wolności, co oznacza, że ekspert lepiej zna się na swojej dziedzinie niż dyletant i dlatego ma prawo być w niej autorytetem. Przeciwnie totalitarnym zagrożeniem dla wolności jest nieuznawanie autorytetu epistemicznego, gdy wynika ze źle rozumianego egalitaryzmu.

Pewnym ograniczeniem ujęcia Bocheńskiego jest przyjęta przez niego metoda analizy kategorialnej autorytetu, która, choć ujmuje jego podstawowe założenia logiczne w sposób jasny i wyraźny, to jednak bez uwzględnienia jego dynamiki. Można jednak przyjąć, że ów dynamiczny

\footnotetext{
43 Tamże, 117.
}

${ }_{44}$ Tamże, 118. 
aspekt omawianych relacji autorytetu autor pozostawia jako przedmiot dalszych badań, w szczególności na gruncie nauk społecznych.

\section{Bibliografia}

Arendt Hannah. 1961. "What is Authority?". W: Between the Past and the Future. Six Exercises in Political Thought, 91-142. New York: The Viking Press.

Arendt Hannah. 2011. „Co to jest autorytet?”. W: Między czasem minionym a przyszłym. Osiem ćwiczeń z myśli politycznej, przeł. Mieczysław Godyń, Wojciech Madej, 109-73. Warszawa: Aletheia.

Bochenski Joseph M. 1965. The Logic of Religion. New York University Press.

Bochenski Joseph M. 1974. Was ist Autorität? Einführung in die Logik der Autorität. Freiburg: Verlag Herder.

Bocheński Józef Maria. 1979. Qu'est-ce que l'autorité? Introduction à la logique de l'autorité, przeł. Philibert Secrétan. Études d'éthique chrétienne. Fribourg: Éditions Universitaires.

Bocheński Józef Maria. 1990. Logika religii, przeł. Sławomir Magala. Warszawa: Instytut Wydawniczy Pax.

Bocheński Józef Maria. 1993. Co to jest autorytet?, przeł. Jan Parys. W: Józef Maria Bocheński, Logika i filozofia. Wybór pism, przeł. Tadeusz Baszniak, Dariusz Gabler, Jan Garewicz, Sławomir Magala, Jan Miziński, Jan Parys, 187-324. Warszawa: Wydawnictwo Naukowe PWN.

Bocheński Józef Maria. 1993. Logika religii, przeł. Sławomir Magala. W: Logika i filozofia. Wybór pism, przeł. Tadeusz Baszniak, Dariusz Gabler, Jan Garewicz, Sławomir Magala, Jan Miziński, Jan Parys, 325-468. Warszawa: Wydawnictwo Naukowe PWN.

Bocheński Józef Maria. 1994. Sto zabobonów. Krótki filozoficzny słownik zabobonów. Kraków: Philed.

Głombik Czesław. 1996. „Józef M. Bocheński wobec tomizmu”. Przeglad Religioznawczy 1, 179: 83-108.

Kant Immanuel. 2012. Ugruntowanie metafizyki moralności, przeł. Mirosław Żelazny. W: Dzieła zebrane. Prolegomena do wszelkiej przyszłej metafizyki, która ma wystapić jako nauka. Ugruntowanie metafizyki moralności. Metafizyczne podstawy przyrodoznawstwa. Krytyka praktycznego rozumu. T. 3, red. Tomasz Kupś, przeł. Translatorium Filozofii Niemieckiej Instytutu Filozofii UMK, 139-220. Toruń: Wydawnictwo Naukowe UMK.

Kobiela Filip. 2016. „Autorytet epistemiczny w sytuacji epistemicznej”. Filozofia Nauki XXIV, 1, 93: 123-139.

Ricœur Paul. 1995. „Le paradoxe de l'autorité”. Philosophie, Bulletin de Liaison des professeurs de philosophie de l'académie de Versailles, C.R.D.P. 7: 6-12.

Ricœur Paul. 1999. Paradoks autorytetu, tłum. Jacek Migasiński. W: Oświecenie dzisiaj. Rozmowy w Castel Gandolfo, red. Krzysztof Michalski, przeł. Małgorzata Łukasiewicz, Jacek Migasiński, Andrzej Pawelec, 29-44. Kraków: Znak. 


\section{Streszczenie}

Przedmiotem artykułu są podstawowe założenia i konsekwencje logiki autorytetu Józefa M. Bocheńskiego w odniesieniu do współczesnej dyskusji nad kryzysem autorytetu (Hanna Arendt, Paul Ricœur). W artykule przedstawiam odpowiedź na pytanie, czy zaproponowana przez Bocheńskiego analiza kategorialna wystarczająco wyjaśnia problemy i aporie związane z rozumieniem autorytetu oraz wolności. Odpowiedzi na tak sformułowane zagadnienie pragnę udzielić na podstawie historycznej analizy źródłowej jego prac, takich jak Analysis of Authority (1965) i Was ist Autorität? (1974).

Słowa kluczowe: Bocheński, Arendt, Ricoeur, autorytet, relacja, Oświecenie

\section{Controversy over Authority in the Light of Józef M. Bocheński's Analyses against the Background of the Contemporary Reception of the ldeas of the Enlightenment}

\section{Summary}

The subject of the article is the underlying assumptions and consequences of the logic of authority Józef M. Bocheński's concerning the contemporary discussion on the crisis of authority (Hanna Arendt, Paul Ricœur). In the article, I present an answer to the question of whether the categorical analysis proposed by Bocheński sufficiently explains the problems and aporias related to the understanding of authority and freedom. I want to answer this question based on a historical source analysis of his works, such as Analysis of Authority (1965) and Was ist Autorität? (1974).

Keywords: Bocheński, Arendt, Ricoeur, authority, relations, the Enlightenment 